\title{
Bahasa dan Gender dalam Film Kartun Go Diego Go dan Dora the Explorer: Sebuah Kajian Sosiolinguistik
}

\author{
Haira Rizka \\ IAIN Syekh Nurjati Cirebon
}

\begin{abstract}
This research aims to analyze linguistic characteristics of main characters of Go Diego Go and Dora the Explorer; describe social and cultural factors influencing the use of their linguistic characteristics; anddescribe gender representation reflecting in the movies. The research problems are investigated by employing Pan's theory of language and gender.This is a descriptive qualitative research.The data source of this research is Go Diego Go and Dora the Explorer movies with two randomly selected episodes. The data were collected through observation and note taking technique. The collected data were then analyzed by employing textual analysis method. The research reveals that Dora uses more standard form of phonology, uses more emotional and hyperbole vocabulary, and topics related to daily activity, while Diego does not show these characteristics; the two characters do not use rude or taboo words, question tag, and hyper-correction; different-social status and roles are the factors of different-linguistic characteristics; and gender stereotype reveals that Diego to tell science and technology, while Dora to tell domestic stories and neighborhood.
\end{abstract}

Keywords: language, gender, Diego, Dora, cartoon

DOI: $10.22515 /$ bg.v2i2.1013 


\section{Pendahuluan}

Dora the Explorer merupakan sebuah film animasi yang sukses dibuat oleh Nickelodeon di Amerika Serikat. Sejak pertama kali tayang pada 14 Agustus 2000, film kartun ini telah menjadi acara favorit anak-anak usia prasekolah (PAUD). Menurut data yang dilansir Nielsen Media Research(Seidman, 2011), di tahun 2011 Dora the Explorer ditonton oleh sekitar 1,9 juta anak usia prasekolah setiap harinya. Kartun ini kemudian ditayangkan di 74 negara dan diterjemahkan ke dalam 23 bahasa (Havrilla, 2010, p.10).

Film kartun ini bercerita tentang seorang anak perempuan Latin berumur 7 tahun bernama Dora yang menjelajahi hutan bersama teman-temannya, Boots, Backpack, Map, dan lainnya. Ketika menjelajahi hutan mereka menemukan petualangan-petualangan menarik yang dipecahkan secara logis. Mereka juga mengajak penonton untuk ikut memecahkan masalah yang dihadapi melalui interaksi. Menurut (Corta, Mariana Diaz Wionczek, \& Valeria O. Lovelace, 2014) interaksi yang terdapat dalam film kartun ini mendorong anak untuk belajar menggunakan kecerdasan bahasa mereka. Hal ini karena anak belajar memahami perintah, instruksi, ataupun pertanyaan dari tokoh film kartun Dora the Explorer. Interaksi ini membedakan film kartun ini dengan film kartun yang lain. Interaksi antara tokoh dalam film kartun Dora the Explorer dengan penontonnya berdasarkan 7 hal, yakni logika, musik, kinestetik, interpersonal, intrapersonal, spasial, dan bahasa (Corta et al., 2014). Dalam interaksinya, selain menggunakan bahasa Inggris para tokoh film kartun ini juga menggunakan bahasa Spanyol yang menunjukkan identitas Dora sebagai seorang anak Latin.

Sama halnya dengan film kartun Dora the Explorer, film kartun Go Diego Go, yang muncul pada tahun 2005, bercerita tentang seorang anak laki-laki berumur 8 tahun yang berpetualang mencari ilmu pengetahuan bersama dengan teman-temannya. Topik yang sering dikisahkan dalam film ini adalah ilmu pengetahuan, teknologi, dan fenomena alam.

Kedua film kartun tersebut didedikasikan untuk anak-anak. Hanya saja karena tokoh utama dari kedua film tersebut berbeda, maka fitur kebahasaan yang digunakan oleh keduanya berbeda. Hal ini sejalan dengan pernyataan Lakoff (Hidayati, 2015) yang menyatakan bahwa pria dan wanita memiliki ciri bahasa yang berbeda. Perbedaan tersebut muncul baik di level semantik, sintaksis, fonologi, maupun wacana.

Peneliti berasumsi bahwa film kartun Go Diego Go ditujukan untuk anak laki-laki, sedangkan film kartun Dora the Explorer ditujukan untuk anak perempuan. Asumsi ini didasarkan pada karakter utama tiap-tiap film kartun, yakni Go Diego Go dengan tokoh utama seorang anak laki-laki dan Dora the Explorer dengan tokoh utama seorang anak perempuan. Lebih lanjut asumsi ini didasarkan pada topik berbeda yang ditayangkan pada tiap-tiap film kartun. Go Diego Go banyak menceritakan petualangan yang mengungkap sains dan teknologi sedangkan Dora the Explorer banyak menceritakan petualangan putri, 
fabel, dan lingkungan sekitar. Penelitian serupa pernah dilakukan oleh Hidayati (2015) yang mengkaji fitur kebahasaan dalam film Cars dan Barbie and 12 Dancing Princess. Hidayati menyimpulkan bahwa perbedaan fitur kebahasaan dua gender dalam film tersebut adalah pria lebih sering menggunakan bahasa informal dari pada wanita; dan faktor sosial yang memengaruhi perbedaan fitur kebahasaan keduanya adalah participants. Penelitian ini berbeda dengan penelitian sebelumnya dari segi teori yang digunakan dimana penelitian sebelumnya menggunakan teori Lakoff (1975) sedangkan penelitian ini menggunakan teori (Pan, 2011). Perbedaan teori yang digunakan menghasilkan temuan penelitian yang berbeda. Sementara itu, subjek penelitian sebelumnya adalah film kartun untuk anak-anak usia sekolah dasar atau menengah pertama, sehingga peneliti ingin melihat fitur kebahasaan dua gender di usia tersebut, sedangkan subjek penelitian ini adalah film kartun untuk anakanak usia dini, dimana peneliti ingin melihat fitur kebahasaan dua gender sejak dini.

Berdasarkan asumsi di atas, penelitian ini bertujuan untuk: (1) menganalisis karakteristik kebahasaan tokoh utama laki-laki dan perempuan pada film kartun Go Diego Go dan Dora the Explorer; (2) mendeskripsikan faktor-faktor sosial yang memengaruhi penggunaan karakteristik kebahasaan tersebut; dan (3) mendeskripsikan representasi gender yang tercermin dalam dua film kartun tersebut. Untuk menjawab rumusan masalah, penelitian ini menggunakan teori (Pan, 2011) tentang karakteristik kebahasaan pria dan wanita, faktor sosial dan budaya yang memengaruhi pengunaan kebahasaan pada tiap-tiap gender, dan representasi gender pada bahasa.

Menurut (Speer, 2005) bahasa bergantung dengan penggunanya. Oleh karena itu, analisis bahasa dapat dilakukan dengan meneliti penggunanya. Meskipun demikian, setiap pengguna bahasa tidak menggunakan ragam bahasa yang sama. Terdapat beberapa faktor sosial yang memengaruhi penggunaan bahasa, seperti struktur sosial, kekuatan, gender, pendidikan, pekerjaan, penghasilan, dan umur.

Perbedaan gender dalam masyarakat dikenal dengan pria (male) dan wanita (female) memengaruhi beberapa aspek kebahasaan baik dari tingkat semantik maupun sintaksis. Teori (Pan, 2011) memaparkan bahwa secara garis besar pria dan wanita memiliki perbedaan kebahasaan baik dari tingkat fonologi, kosakata, gramatikal, serta topik dan gaya percakapan. Secara rinci (Pan, 2011)menjabarkan ciri kebahasaan wanita antara lain: (1) cenderung menggunakan pelafalan kata yang lebih benar dan standar dari pada pria, (2) biasanya berbicara dengan nada yang lebih tinggi dari pada pria, (3) intonasi berbicara terdengar lebih emosional, lembut, dan penuh kasih sayang, (4) lebih sering menggunakan intensifier (kata penguat) seperti so, much, quite, vastly, dll, (5) sering menggunakan kata sifat dan kalimat hiperbola, (6) cenderung menghindari kata-kata bermakna kasar atau tabu, (7) sering menggunakan eufemisme (ungkapan yang lebih halus) dan ekspresi kesopanan, (8) sering menggunakan kalimat question tag, (9) banyak ditemukan hyper-correction 
pada grammatical, (10) sering menggunakan hedges (ekspresi yang menyatakan keraguraguan terhadap informasi yang disampaikan), (11) subjek pembicaraan biasanya tentang baju, warna, dan dunia yang dekat dengan perempuan, dan (12) cenderung menggunakan percakapan sebagai wadah untuk bernegosiasi, mendukung, dan memperoleh kesepakatan. Sementara itu, ciri bahasa pria adalah lawan dari ciri-ciri tersebut.

Sementara itu (Pan, 2011)menyatakan bahwa terdapat faktor sosial dan faktor budaya yang memengaruhi penggunaan kebahasaan pada gender yang berbeda. Secara sosial, kebahasaan wanita dan pria terbentuk karena: (1) adanya status sosial yang melekat pada wanita yang menyatakan bahwa secara ideologi dan pemikiran, pria lebih jelas dibandingkan wanita; dan (2) adanya peran sosial yang berbeda antara kedua gender tersebut yang menyatakan bahwa wanita dipandang sebagai makhluk yang lebih terancam, bergantung pada orang lain, dan lebih emosional dibandingkan pria, dan mungkin saja faktor-faktor ini muncul karena cara pengasuhan yang berbeda. Sementara itu faktor budaya yang memengaruhi penggunaan adalah (1) sistem gender dalam masyarakat yang menyatakan bahwa pria lebih unggul dari pada wanita, pemimpin keluarga, petarung politik, dll; (2) ideologi gender yang menyebabkan perbedaan pandangan terhadap kedua gender, khususnya dari segi linguistik.

Bahasa merupakan produk budaya dan pemikiran suatu kelompok. Bahasa kemudian menjadi salah satu alat untuk melabelkan suatu kelompok (stereotyping). Kamus Besar Bahasa Indonesia mendefinisikan stereotip sebagai konsepsi mengenai sifat suatu golongan berdasarkan prasangka yang subjektif dan tidak tepat. Dari definisi ini jelas bahwa stereotip menjadi sebuah alat untuk membentuk sebuah ide atau pemikiran tentang suatu konsep. Definisi ini juga mengatur bagaimana seseorang atau sesuatu seharusnya berdasarkan ide yang dimiliki oleh masyarakat. Menurut Fakih (Hidayati, 2015) stereotip atau pelabelan semacam itu terkadang menyebabkan ketidakadilan pada suatu kelompok. Dalam struktur masyarakat stereotip tentang gender sering memberikan ketidakadilan atau dampak negatif kepada wanita.

Menurut (Duranti, 1997, p.210) berpendapat bahwa ekspresi dan strategi linguistik yang melekat sebagai identitas gender tertentu memiliki hubungan yang erat dengan hubungan sosial. Sebagai contoh, di Inggris tuturan wanita banyak menggunakan tag question. Dengan demikian, ketika ada seseorang yang sering menggunakan tag question dalam tuturannya maka secara langsung akan diasosiasikan dengan feminine(Duranti, 1997, p.211). Hal ini hanya karena tag question banyak digunakan oleh wanita. Begitu pula dengan penggunaan kata-kata sopan yang langsung diasosiasikan dengan wanita dan kata-kata kasar dengan pria. Menurut (Hidayati, 2015, p.144) hal yang sama juga terjadi dalam film kartun Cars dan Barbie and 12 Dancing Princess dimana Cars merepresentasikan gender pria sebagai makhluk yang pemberani dan tegas, sedangkan Barbie and 12 Dancing Princess merepresentasikan gender wanita sebagai makhluk yang menyukai keindahan. Sementara itu, penelitian ini 
melihat representasi gender untuk anak usia dini pada film kartun Go Diego Go dan Dora the Exploreri dari segi topik yang dilekatkan pada dua gender.

Penelitian ini merupakan penelitian kualitatif yang mendeskripsikan fenomena pada konteks tertentu (Vanderstoep \& Deirdre D. Johnston, 2009, p.35). Dengan menggunakan metode ini, peneliti tidak memiliki kontrol terhadap variabel penelitian. Maka peneliti hanya melaporkan dan mendeskripsikan fenomena yang terjadi. Sumber data penelitian ini adalah video film kartun Go Diego Go dan Dora the Explorer dengan 2 episode yang dipilih secara acak (random). Karena penelitian ini menganalisis fenomena kebahasaan di kedua film kartun tersebut, maka data dalam penelitian ini berupa tuturan baik dalam bentuk kata, frasa, kalimat, maupun wacana.

Untuk mengumpulkan data, peneliti menggunakan teknik observasi dan catat yang memungkinkan peneliti untuk menganalisis sebuah fenomena (Kesuma, 2007, p.43). Data yang terkumpul kemudian dianalisis menggunakan metode analisis tekstual. Metode ini sangat tepat karena memungkinkan peneliti untuk menganalisis fenomena kebahasaan dan gender.

\section{Penggunaan Bahasa Kartun Go Diego Go dan Dora the Explorer}

Hasil penelitian menunjukkan bahwa terdapat 12 karakteristik kebahasaan yang digunakan oleh pemeran utama pria dalam film kartun Go Diego Go dan pemeran utama wanita dalam film kartun Dora the Explorer. Sementara itu faktor sosial dan budaya sangat erat memengaruhi perbedaan fenomena kebahasaan pada kedua gender. Perbedaan tersebut kemudian menimbulkan pelabelan gender (stereotyping).

\section{Karakteristik Bahasa KartunGo Diego Go dan Dora the Explorer}

Dora karakter utama dalam film kartun Dora the Explorer memiliki karakteristik bahasa yang berbeda dengan Diego, karakter utama dalam film kartun Go Diego Go. Perbedaan itu terlihat di beberapa aspek kebahasaan.

Dari aspek fonologi, Dora menggunakan pelafalan yang lebih jelas dari pada Diego. Tuturan yang diucapkan oleh Diego tidak terlalu jelas sehingga terkadang membuat bingung. Perbedaan dalam tataran fonologi juga muncul pada nada (pitch atau tone). Dora banyak menggunakan nada tinggi (higher pitch) ketika berbicara dan berkomunikasi dengan lawan tuturnya. Sementara itu Diego menggunakan nada bicara yang normal atau tidak menggunakan nada yang tinggi. 
DORA: Help me put the ring on my finger!

Bantu aku meletakkan cincin di jariku!

DIEGO: Do you want to go to the dinosaur adventure? Come one!

Apakah kamu mau ikut ke petualangan dinosaurus? Ayo berangkat!

Dari dua contoh di atas dapat dilihat perbedaan intonasi ketika berbicara. Dora lebih banyak menggunakan rising intonation (intonasi naik) di banyak bagian dalam percakapannya. Sementara itu, Diego menggunakan normal intonation (intonasi normal) dan falling intonation (intonasi turun) yang menunjukkan kalimat tanya.

Penggunaan intonasi naik yang banyak ditemukan pada ujaran Dora menunjukkan emotional tone (intonasi emosi). Dora ingin mengajak lawan tuturnya untuk ikut berpetualang dengannya. Oleh karena itu, untuk memastikan bahwa lawan tuturnya memahami apa yang dia ucapkan, maka Dora menggunakan banyak emotional tone. Hal ini bisa diasumsikan bahwa sejak dini, wanita telah memiliki emotional tone dalam percakapannya. Berbeda dengan Dora, Diego tidak banyak menggunakan emotional tone. Dalam tuturannya yang bertujuan untuk mengajak lawan tuturnya ikut berpetualang, Diego menggunakan normal tone. Meskipun demikian, dia tetap meyakinkan lawan tuturnya untuk memahami dan ikut berpetualang dengannya. Perbedaan intonasi kedua tokoh tidak menyebabkan perbedaan respon lawan tutur karena keduanya berhasil mendapatkan perhatian lawan tutur. Perbedaan tersebut muncul karena karakteristik intonasi yang berbeda dimana Dora menggunakan emotional tone sedangkan Diego menggunakan normal tone.

Dari segi pemilihan kosakata, ciri kebahasaan dua tokoh utama berbeda gender menunjukkan perbedaan yang mencolok. Karakteristik lain yang juga banyak ditemukan dalam percakapan Dora adalah penggunaan intensifier. Karakteristik kebahasaan ini meliputi penggunaan kata yang bermakna kekaguman ketika mengekspresikan sesuatu. Dalam percakapnnya, Dora banyak sekali menggunakan kata wow yang bertujuan untuk mengekspresikan perasaannya ketika melihat sesuatu yang baru atau berhasil menyelesaikan sebuah pekerjaan.

\section{DORA:Wouw mirra! Whose ring are these?}

Wouw Mirra! Siapa pemilik cincin ini?

Konteks pada tuturan ini adalah Dora, dengan dibantu lawan tuturnya, telah berhasil mendapatkan cincin. Dia sangat senang dan mengekspresikannya dengan mengatakan wow mirra! Jenis ekspresi semacam ini banyak sekali ditemukan dalam tuturan Dora. Lebih 
lanjut Dora juga banyak menggunakan jenis intensifier seperti so, pretty, much, very, dan nice untuk menunjukkan kekaguman dan bahagia. Semua kata tersebut digunakan untuk mengekspresikan rasa bahagia.

Sementara itu, dalam tuturannya, Diego tidak banyak menggunakan intensifier untuk mengekspresikan sesuatu atau perasaannya. Sebagai contoh, ketika dia berhasil menyelesaikan misinya untuk mengumpulkan semua telur dinosurus, dia hanya menyatakan kekagumannya dengan menggunakan kalimat positif.

DIEGO:You complete! You are an animal rescuer!

Kamu telah berhasil. Kamu adalah penyelamat hewan!

Pemilihan kata yang dilakukan oleh Diego menunjukkan sedikit sekali penggunaan intensifier. Meskipun dia sedang mengekspresikan kegembiraaanya telah menyelesaikan misi mengumpulkan semua telur dinosaurus, dia hanya mengatakan 'kamu berhasil'. Tuturan Diego berupa kalimat informatif yang hanya menyatakan bahwa lawan tutur telah berhasil melakukan misinya. Dalam tuturannya, Diego tidak menyisipkan intensifier, yakni kata-kata seperti 'benar-benar, hebat, hebat sekali, atau menakjubkan' yang bisa digunakan untuk menunjukkan rasa bangga atau apresiasi pada lawan tutur.Dengan demikian dapat disimpulkan bahwa kalimat informatif sudah cukup untuk memberikan apresiasi pada lawan tutur sehingga intensifier tidak diperlukan.

Karakteristik lain yang muncul dalam tuturan Dora adalah banyaknya penggunaan kata sifat dan hiperbola. Dora menggunakan bentuk ini untuk menyatakan ketakjuban atau pujian atas keberhasilan misi yang telah diselesaikan atau kemauan untuk ikut melakukan suatu pekerjaan. Lebih lanjut, karakteristik bentuk ini mewakili perasaan Dora.

DORA : This is going to be the hardest thing I've ever tried to do.

Ini akan menjadi pekerjaan yang paling sulit yang pernah aku lakukan!

Bentuk hiperbola muncul pada salah satu contoh tuturan Dora. Tuturan tersebut muncul pada saat Dora akan memulai petualangan untuk menyelamatkan Boots. Ekspresi 'the hardest thing I've ever tried to do' merupakan jenis hiperbola karena Dora membesarbesarkan pekerjaan yang akan dia lakukan. Lebih lanjut dia merasa tidak percaya diri dengan kemampuan yang ia miliki. Oleh karena itu, kalimat pada contoh ini dianggap sebagai bentuk hiperbola.

Sementara itu dalam percakapannya, Diego menggunakan kata sifat dalam tuturannya meskipun jumlahnya tidak sebanyak dengan penggunaan kata sifat pada tuturan Dora. Sedangkan kalimat yang bermakna hiperbola tidak ditemukan dalam tuturan Diego. Ketika 
dia bahagia telah menyelesaikan sebuah misi atau takjub dengan sesuatu yang dilihat, dia lebih memilih untuk mengekspresikannya dengan kalimat informatif.

DIEGO: You discovered dinosaur bone!

Kamu telah menemukan tulang dinosaurus.

Ketika telah berhasil menemukan tulang dinosaurus dengan dibantu oleh penonton (lawan bicara), Diego tidak memberikann pujian berupa kata sifat, melainkan mengekspresikannya berupa kalimat informatif. Dia mengatakan bahwa penonton telah menemukan tulang dinosaurus. Kalimat ini sebenarnya memiliki makna secara tidak langsung menyatakan bahwa kamu telah berhasil. Dengan kata lain, ini adalah sebuah bentuk kalimat pujian yang tidak muncul dalam bentuk kata sifat. Hal ini dapat diasumsikan bahwa, karena gender wanita memiliki fitur emotion yang kuat (Speer, 2005, p.22), dalam tuturannya Dora banyak memproduksi kata-kata yang bersifat emotional seperti penggunaan adjectives maupun kalimat hiperbola. Sebaliknya, gender pria tidak memiliki fitur emotion, dalam tuturannya Diego banyak memproduksi kata-kata yang bersifat emotional seperti penggunaan adjectives maupun kalimat hiperbola.

Sementara itu ciri kebahasaan menghindari kata-kata kasar atau tabu ditemukan pada kedua tokoh tersebut. Hal ini dimungkinkan karena kedua film kartun tersebut ditujukan untuk anak-anak sehingga kata-kata kasar dan tabu tidak ditemukan. Jenis bahasa yang digunakan dalam film ini adalah bahasa yang bersifat mendidik, memotifasi, dan menghibur anak-anak. Sebaliknya, eufemisme dan ekspresi kesopanan banyak ditemukan dalam film kartun Go Diego Go dan Dora the Explorer.

DORA : (confused with Giant's language) Ohh. It sounds like the Giant feels grumpy. Excuse me, Senior Gigantea. What's the matter?

(Kebingungan dengan bahasa Giant) Ohh. Sepertinya Giant sedang merasa sedih. Permisi, Senior Gigantea. Apa yang terjadi?

\section{DIEGO:Would you please find fruits for each dinosaur?}

Maukah kamu menemukan buah-buahan untuk setiap dinosaurus?

Contoh (7) dan (8) menunjukkan bahwa kedua tokoh menggunakan kata-kata yang bersifat sopan dan mendidik, Dora menunjukkan bagaiaman cara menyapa seseorang dengan mengatakan 'permisi' dan Diego menunjukkan bagaimana cara meminta tolong dengan menggunakan ekspresi yang sopan dengan mengatakan 'would you please'.

Banyak teori yang mengatakan bahwa bahasa wanita lebih sopan dari pada bahasa pria. Meskipun demikian, bahasa pria bisa menjadi sopan seperti halnya bahasa wanita. Hal ini seperti yang dikemukakan oleh (Duranti, 1997, p.210) bahwa beberapa ekspresi atau strategi 
linguistik yang umumnya digunakan oleh pria juga digunakan oleh wanita. Begitupun sebaliknya. Dengan kata lain, konteks atau situasi menyebabkan pembicara menggunakan fitur bahasa tertentu meskipun fitur tersebut tidak umum digunakan oleh pembicara.

Sementara itu, untuk menunjukkan kesopanan seorang pembicara bisa juga menggunakan hedges. Fitur kebahasaan jenis ini banyak ditemukan dalam tuturan Dora. Dibanyak situasi dia banyak mengatakan 'In think, in my opinion, atau you know'. Ekspresiekspresi ini digunakan untuk menunjukkan rasa tidak sepenuhnya percaya dengan pengetahuan yang dimiliki sehingga memerlukan pendapat orang lain. Hedges semacam ini juga digunakan untuk menunjukkan rasa kesopanan karena melibatkan orang lain.

DORA:We need to bring the moon to the queen and king. But it's up so high in the sky. I think we need some help from our friend.

(Kita harus membawa bulan kepada ratu dan raja. Tapi, bulan berada di langit yang sangat tinggi. Aku pikir kita perlu bantuan teman-teman.

Tuturan Dora pada contoh di atas menunjukkan bahwa dia memerlukan bantuan orang lain yang diyakini bisa membantu dan menyelesaikan pekerjaannya. Ini adalah jenis kesopanan yang dilakukan oleh Dora karena dia menganggap orang lain, dan tidak merasa cukup dengan kemampuannya sendiri. Contoh semacam ini banyak ditemukan dalam tuturan Dora, dia menganggap kemampuan orang lain untuk bisa membantu dan menyelesaikan masalahnya. Fitur kebahasaan semacam ini tidak ditemukan dalam tuturan Diego. Berbeda dengan Dora, Diego melakukan suatu pekerjaan sendiri jika dia merasa bisa menyelesaikannya, atau dia akan menggunakan kalimat perintah ketika ingin meminta bantuan orang lain.

Secara gramatikal, question tag tidak ditemukan pada tuturan kedua tokoh utama. Baik Dora maupun Diego masih dalam tahap perkembangan bahasa. Sementara itu, pengetahuan tentang question tag memerlukan pengetahuan bahasa yang sudah kompleks. Oleh karena itu, question tag tidak muncul dalam percakapan keduanya. Hal yang sama juga terjadi dengan hypercorrection. Kedua tokoh utama tidak menggunakan hypercorrection dalam tuturan mereka karena keduanya masih dalam masa perkembangan pemerolehan bahasa. Dengan kata lain, karena kemampuan bahasa keduanya belum sempurna, maka tidak ditemukan hypercorrection. Meskipun demikian, kedua tokoh utama ini tidak menunjukkan adanya kesalahan gramatikal dalam tuturan mereka.

Sementara itu, topik pembicaraan maupun gaya bahasa kedua tokoh utama ini sangat berbeda. Sebagai tokoh utama wanita dalam film kartun Dora the Explorer, Dora kebih banyak bercerita tentang petualangannya dengan tokoh-tokoh dunia dongeng seperti putri, raja, ratu, kurcaci, raksasa, atau nenek sihir; orang-orang di sekitarnya seperti ayah, ibu, guru, 
atau teman. Hal ini bisa diasumsikan bahwa wanita lebih menyukai topik-topik bertemakan fabel dan lingkungan sosial yang dekat. Berbeda dengan Dora, Diego tokoh utama pria dalam film kartun Go Diego Go lebih banyak membicarakan petualangan tentang sains, alam, tumbuhan, hewan, tata surya, atau teknologi. Hal ini bisa diasumsikan bahwa pria memiliki ketertarikan pada topik-topik tersebut sehingga Diego lebih banyak bercerita tentang topik tersebut.

Lebih lanjut, selama petualangannya, Dora banyak melibatkan warna baik untuk memecahkan suatu masalah. Ketika menyebutkan suatu benda, Dora lebih sering menspesifikkan benda tersebut berdasarkan warna, bukan berdasarkan klasifikasi lain seperti bentuk, ukuran, atau jumlahnya. Sementara itu, Diego tidak menggunakan warna dalam percakapannya. Dia lebih banyak menggunakan bentuk-bentuk bangun atau menghitung jumlah suatu benda untuk memecahkan suatu masalah.

DORA:Now try to find all the green jewels!

(Sekarang kita coba untuk menemukan semua permata berwarna hijau!)

DIEGO:At the end of each journey, you will put the dinosaurs on thejournals?

Maukah kamu menemukan buah-buahan untuk setiap dinosaurus?

Dora menspesifikkan betuk permata yang harus ditemukan menjadi 3 warna: hijau, merah, dan kuning. Sementara itu, Diego tidak mengkhususkan jurnal yang harus diisi meskipun terdapat 4 jurnal yang harus diisi. Diego megeneralisasi objek tersebut dengan hanya menyebutkan 'journals'. Bentuk $-s$ dalam kata tersebut jelas nunjukkan bahwa ada beberapa jurnal (jamak) dan bersifat umum.

Dari kedua contoh di atas, dapat ditarik kesimpulan bahwa wanita memiliki kecenderungan untuk mengkhususkan suatu benda berdasarkan warna, sedangkan pria memiliki kecenderungan untuk mengeneralisasi suatu objek atau menspesifikkannya berdasarkan bentuk, ukuran, atau jumlahnya.

\section{Faktor Sosial dan Budaya}

Masyarakat telah dengan jelas membuat kotak-kotak klasifikasi status sosial antara pria dan wanita. Status sosial yang berbeda antara pria dan wanita menyebabkan kedua gender ini memiliki kedudukan yang berbeda sehingga memengaruhi beberapa lini kehidupan. Gender secara sosial melekat pada kaum laki-laki maupun perempuan yang dikonstruksi secara sosial maupun kultural, yang menyampaikan kepada orang lain bahwa seseorang adalah feminin atau maskulin, yang dilihat dari penampilan, pakaian, sikap, kepribadian, bekerja di dalam 
dan di luar rumah tangga, seksualitas, tanggung jawab keluarga, atau yang memoles peran gender seseorang(Wiyatmi, 2010, p.199). Pembagian konsep publik-privat, wanita menempati fungsi privat dengan urusan rumah tangga, pengasuhan anak, dan keluarga, wanita memiliki tanggung jawab mengatur urusan reproduksinya. Laki-laki yang menempati sektor publik dianggap tidak memiliki kewajiban dengan reproduksi urusan privat(Udasmoro, 2004, p.152). Hal yang sama juga terjadi dengan budaya suatu kelompok yang membedakan peran dua gender yang ada, pria dan wanita. Kedua karakter ini kemudian membentuk sebuah konsep yang menyebabkan satu gender berperilaku berbeda dari gender yang lain.

Dalam film kartun Go Diego Go dan Dora the Explorer, faktor sosial budaya terlihat jelas membentuk fitur kebahasaan kedua tokoh dalam film kartun ini. Sebagai anak perempuan, Dora memiliki status sosial yang berbeda dari Diego. Dora dianggap lebih baik membicarakan hal-hal domestik dari pada hal-hal yang bersifat petualangan yang liar. Oleh karena itu, meskipun bersifat petualangan, kebanyakan topik dalam film kartun ini membicarakan tentang fabel dan lingkungan sekitarnya. Sementara itu, tokoh utama pria dalam film kartun Go Diego Go diangap lebih kuat dan bisa memahami dunia lebih luas sehingga topik yang dibicarakan dalam film kartun ini adalah sains, alam, tumbuhan, hewan, tata surya, atau teknologi.

Hal semacam ini bisa saja terjadi karena masyarakat menganggap bahwa kedua gender ini memiliki peran sosial yang berbeda. Laki-laki menyukai topik bisnis, politik, hukum, pajak, dan olahraga, sedangkan perempuan memilih masalah sosial, buku, makanan dan minuman, kehidupan, dan gaya hidup (S.H Wijayanti \& Y.C. Dhian, 2012, p.188). Perempuan dikenal lemah lembut, cantik, emosional, dan keibuan, sedangkan laki-laki dianggap kuat, rasional, perkasa, dan jantan(Zaduqisti, 2009, p.75). Masyarakat menganggap wanita sebagai makhluk yang lembut dengan penuh imajinasi dan menyukai hal-hal domestik sehingga bahasa yang digunakan serta ide yang dikeluarkan oleh anak perempuan berupa hal-hal yang tidak jauh dengan dunia mereka. Begitu pula dengan anak laki-laki yang dianggap oleh masyarakat memiliki peran yang tentu saja berbeda dari anak perempuan. Anak laki-laki dianggap lebih mampu untuk memahami dunia luas, kuat, dan menyukai cerita petualangan tentang alam sekitar. Hal ini kemudian menyebabkan kebahasaan anak laki-laki berbeda dari perempuan.

\section{Stereotip Gender}

Kamus Besar Bahasa Indonesia mendefinisikan stereotip sebagai konsepsi mengenai sifat suatu golongan berdasarkan prasangka yang subjektif dan tidak tepat. Dari definisi ini jelas terlihat bahwa konsep suatu pandangan terbentuk oleh prasangka masyarakat yang menentukan aturan yang baik maupun tidak baik bagi seseorang berdasarkan kelas- 
kelas yang mereka bentuk. Stereotip juga jelas mengatur apa yang pantas dan tidak pantas dilakukan oleh seseorang berdasarkan kelas yang telah dibuat. Dalam masyarakat, konsep gender menyebabkan stereotip yang sangat mencolok dalam masyarakat. Stereotip gender mengatur perilaku manusia yang dibagi menjadi dua kelas, yakni pria dan wanita. Stereotip gender merumuskan bagaimana seharusnya pria dan wanita berpikir, merasa, dan berbuat (Zaduqisti, 2009, p.75). Satu stereotip di masyarakat adalah perempuan lebih banyak berbicara daripada laki-laki, berbicara ihwal topik personal seperti keluarga, sahabat, emosi, sebaliknya laki-laki menyukai topik publik seperti olahraga, politik, atau masalah faktual lainnya (Wijayanti \& Dhian, 2012, p.188).

Dalam film kartun Dora the Explorer maupun Go Diego Go terlihat jelas stereotip gender pada fitur kebahasaan tokoh utamanya. Dora sebagai anak perempuan mendapat label sebagai seorang tokoh yang memiliki peran domestik sehingga topik yang diceritakan dalam film kartun ini adalah masalah-masalah yang dekat dengan dunia perempuan seperti cerita fabel beserta tokohnya, lingkungan sekitar beserta penghuninya. Sementara itu, Diego, seorang anak laki-laki yang mendapat label sebagai tokoh yang memiliki kemampuan untuk berpetualang lebih luas. Oleh karena itu, topik yang dibicarakan dalam film kartun Go Diego Go adalah hal-hal yang berkaitan dengan ilmu pengetahuan dan teknologi (IPTEK). Diego sama sekali tidak membahas cerita dongeng (fabel) maupun lingkungan sekitar dengan penghuninya. Begitupun sebaliknya. Dora sama sekali tidak membicarakan ilmu pengetahuan dan teknologi. Fenomena semacam ini bisa terjadi karena ekspresi kebahasaan baik dari segi gramatikal, kosakata, topik, diasosiasikan adanya sikap tertentu yang dilabelkan pada gender tertentu (Duranti, 1997, p.210).

\section{Kesimpulan}

Go Diego Go dan Dora the Explorer merupakan dua film kartun anak dengan tokoh utama Diego, seorang anak alaki-laki, dan Dora, seorang anak perempuan. Kedua tokoh dalam film kartun ini menunjukkan fenomena kebahasaan yang unik karena perbedaan gender pada keduanya.

Hasil penelitian menunjukkan bahwa karakteristik kebahasaan yang sering digunakan oleh Dora antara lain: pelafalan kata yang lebih benar dan standar, nada yang lebih tinggi, intonasi berbicara terdengar lebih emosional, lembut, dan penuh kasih sayang, penggunaan intensifier (kata penguat), penggunaan kata sifat dan kalimat hiperbola, penggunaan hedges, subjek pembicaraan biasanya tentang baju, warna, dan dunia yang dekat dengan perempuan, dan cenderung menggunakan percakapan sebagai wadah untukbernegosiasi, mendukung, dan memperoleh kesepakatan. Sebaliknya, Diego tidak menunjukkan penggunaan karakteristik kebahasaan tersebut. Sementara itu, menghindari kata-kata bermakna kasar atau tabu dan 
penggunaa eufemisme banyak ditemukan oleh dua tokoh utama karena kedua film kartun tersebut bersifat mendidik anak. Sementara itu, karakteritsik penggunaan kalimat question tag dan hyper-correction tidak ditemukan pada keduanya karena kedua tokoh tersebut adalah anak-anak yang belum memiliki kemampuan bahasa yang sempurna.

Sementara itu faktor sosial budaya terlihat jelas memengaruhi penggunaan kebahasaan yang berbeda dari kedua tokoh tersebut. Status dan peran sosial yang berbeda menyebabkan penggunaan bahasa yang berbeda pada keduanya. Anak perempuan dianggap lebih memahami urusan domestik dan dongeng sehingga film kartun Dora the Explorer banyak bercerita tentang fabel, lingkungan sekitar, keluarga, dan teman. Sementara itu, Diego sebagai anak laki-laki dianggap sebagai tokoh yang mampu untuk memahami dunia lebih luas sehingga film kartun ini banyak bercerita mengenai ilmu pengetahuan dan teknologi. Hal ini kemudian menjadikan stereotip gender pada keduanya.

\section{Referensi}

Corta, C. E., Mariana Diaz Wionczek, \& Valeria O. Lovelace. (2014). Exploring the Media with Dora: A Pre-School Introduction to Media Literacy. California: The Journal of Media Literacy, 72(17). Retrieved from http://journalofmedialiteracy.org/index.php/ current-issue/96-david-considines-ten-technology-tips-for-principals

Duranti, A. (1997). Linguistic Anthropology. Cambridge: Cambridge University Press.

Havrilla, K. (2010). A Sociological Influence in Dora the Explorer: American Sociological Association.

Hidayati, N. N. (2015). Karakteristik Kebahasaan Tuturan Laki-Laki dan Perempuan dalam Film Anak: Studi Kasus Film Cars dan Barbie and 12 Dancing Princess. Universitas Gadjah Mada.

Kesuma, T. M. J. (2007). Pengantar (Metodologi) Penelitian Bahasa. (S. M. Sihalo, Ed.). Yogyakarta: Carasvatibooks.

Pan, Q. (2011). On the Features of Female Language in English, Theory and Practice in Language Studies. Retrieved from https: //doi:10.4304/tpls.1.8.1015-1018

Seidman, R. (2011). Nickelodeon Nabs Basic Cable's Top Spot this Month, Notches AllTime July High with Total Viewers. Retrieved from dihttp://tvbythenumbers.zap2it. com/2011/08/02/nickelodeon-notches-all-time-july-high-with-total-viewers/99481/

Speer, S. A. (2005). Gender Talk. New York: Routledge.

Udasmoro, W. (2004). Konsep Nasionalisme dan Hak Reproduksi Perempuan: Analisis Gender terhadap Program Keluarga Berencana di Indonesia. Jurnal Penelitian Humaniora, 16(2).

Vanderstoep, S. W., \& Deirdre D. Johnston. (2009). Research Methods for Everyday Life. San Fransisco: Jossey-Bass.

Wijayanti, S. ., \& Y.C. Dhian. (2012). Kecenderungan Siswa di Bekasi dalam Memilih Topik Esai Ditinjau dari Perspektif Gender. Jurnal Penelitian Humaniora, 24(2).

Wijayanti, S. H., \& Dhian, Y. C. (2012). Kecenderungan Siswa Sma Di Bekasi Dalam Memilih Topik Esai Ditinjau Dari Perspektif Gender. Humaniora, 24(2). 
Wiyatmi. (2010). Kontruksi Gender dalam Novel Geni Jora Karya Abidah El-Khalieqi. Jurnal Penelitian Humaniora, 22(2).

Zaduqisti, E. (2009). Stereotipe Peran Gender bagi Pendidikan Anak. Jurnal Muwazah, 1(1). 